\title{
THE SOCIAL TEACHING OF PAUL.
}

\section{THE APOCALYPTIC MESSIANISM OF THE PHARISEES.}

By SHAILER MATHEWS,

The University of Chicago.

While thus the messianism of the masses, following blindly in the path of the older prophetic nationalism, was seeking to establish a regenerate Israel as the precursor of the kingdom of God, that of the literary classes, and of the Pharisees in particular, advanced in the line of apocalyptic. This fact was a natural outcome of the difference between the comfortable and the distressed elements in the Jewish state. The masses wished for a new kingdom in which an end should be made of the actually felt misery born of poverty and social inequality quite as certainly as of the national dishonor of subjection to a heathen power. The Pharisees, enjoying personal comfort and respect, were naturally concerned rather with the more impersonal, if not paradoxical, matter of the establishment of a new Jewish state without revolution or social regeneration. Their hope was in consequence more joined with patience. God, and not man, would bring in the new age. Throughout the three centuries in which the apocalyptic suggestions of Daniel were developed into new doctrines pharisaic messianism became increasingly transcendental. A literary bourgeoisie could well afford to discountenance revolution and await the fulfilment of academic dreams.

Yet the Pharisees, in their early days, were by no means indifferent to politics. The great scribal movement from which they sprang had crystallized first in the party of the Chasidim, and the society of Pharisees had differentiated itself from the older party largely because it saw in national affairs the need of applying its principle of separation. The break between John Hyrcanus and those who had been his family's truest supporters doubtless came from the refusal of the Pharisees to have further 
share in the traditional Asmonean policy of immersing Judea in international politics. The bitter war which the Pharisees had waged with Alexander Jannæus was due to their opposition to the growing monarchy. Under Alexandra, Simon ben Shetach and the Pharisees had been with the government, and had brought great prosperity to the nation. Later they had taken sides in the unhappy struggles between Aristobulus and Hyrcanus II., and had thus been involved in the new political life resulting from the conquest of Judea by Pompey.

But with the rise of the house of Antipater the political interests of pharisaism had weakened. The awakening from a dream of an ideal Israel administered by a Sanhedrin devoted to the oral law, to the rough and ready government of a foreigner supported by a heathen power, was too rude even for their political idealism, and they attempted to reduce Jewish political life to the minimum. Confronted with the alternative of revolt or of submission to such rulers, at first they chose neither. Twice at least did they endeavor to induce the Romans to govern Judea through a provincial official and local Jewish councils rather than through a rex socius, ${ }^{,}$and then, when these requests had been repeatedly refused, the leaders of the society advised submission to rulers, whoever they might be. ${ }^{2}$ Yet even then many of them refused to take a formal oath of allegiance to Herod. ${ }^{3}$

With political hopes thus destroyed, the Pharisees turned with an ever-increasing faith to Jehovah and his law. In his good time deliverance would come to his people. Throughout the period in which revolutionary messianism was developing, the Pharisees, as well as the Sadducees, constituted a party of law and order. Revolution was farthest possible from their plans, and it is their spirit that breathes in the unceasing denunciation of the Zealots in Josephus. That body, though agreeing

I Thus in the appeal to Pompey (though the Pharisees are not mentioned), Ant., xiv, 3:2; and at the probating of .Herod's will, Ant., xvii, I I: I, 2. Cf. also the desires of the high-priest for peace, War, iv, $5: 2$.

${ }^{2}$ Thus Pollio and Sameas counseled submission to Herod, Ant., xiv, $9: 4$; xv, I : I.

3 With the Essenes, they were excused by that monarch (Ant., xv, 10:4; xvii, $2: 4$ ), though fined. 
with the Pharisees in matters of general belief, 4 differed from them radically in all matters pertaining to the kingdom of God. The one attempted to hasten, the other awaited, God's deliverance. ${ }^{5}$

Yet with the Pharisees as with the Zealots messianism was grounded in a sense of misery so abject as to be hopeless except for Jehovah, but this misery was given a purely religious explanation. The world seemed too miserable and wicked for Jehovah's immediate presence, and pharisaism became half deistic and thoroughly dualistic. God had abandoned the evil world, and it was his Memra, his Word, that was present, ${ }^{6}$ and his law rather than the Shekinah was the sign of his regard for men. The misery which the righteous suffered was a punishment for the sins of Israel, 7 though in no way interpreted as evidence of an approaching deliverance. On the contrary, misfortunes were evidence of the existence of a "Prince of the World," or of an Antichrist, the great opponent of God and the future Christ, who was allowed for a time to torment Jehovah's people. Even when not conceived of as transcendent, this opposing personality was ever present in the mind of the pious Pharisee. Antiochus Epiphanes, the dread figure of Daniel; the kings of the Medes and Parthians $;^{8}$ the world of demons with its prince Beelzebuball seemed to explain Israel's misfortunes and to stimulate new faith. 9 The very indefiniteness of this present evil ruler must have made the Pharisee discountenance revolution and look the more eagerly for the interference of Jehovah. The arm of flesh

${ }^{4}$ Ant., xviii, I: 1, 6 ; War, ii, $8:$ r.

5 So far from correct is the undiscriminating statement of EATon, art. "Pharisees," Hastings's Dict. of the Bible, that the Zealots "simply carried out the pharisaic principles to their logical conclusion." The logical conclusions of pharisaic messianism were precisely those exemplified in pharisaism itself - a peaceful awaiting of the coming of the eschatological kingdom of God and the Messiah. For the relations of the two parties see, for instance, War, iv, $3: 9 \mathrm{ff}$.

${ }^{6}$ Assumption of Moses, I0: I ; Enoch, $40: 7$. See, for a somewhat extreme presentation of this entire matter, BAI.DENSPERGER, Das Selbstberusstsein Jesu, chaps. I, 2.

7 Enoch, $89 \mathrm{f}$. See also the Psalms of Solomon, passim.

${ }^{8}$ Enoch, 53 : I f.; $56:$ I f.; $90:$ I f.

9 On Antichrist see Bousset, Der Antichrist; Preuschen, "Paulus als Antichrist," Zeitschrift für die neutestamentliche Wissenschaft, 1901, pp. 169-201. 
would have been weak indeed against the Prince of the power of the air. Thus there grew up the dualistic belief in two opposing kingdoms, that of God and that of Satan; the one peopled with good angels, the other with demons and evil angels. Humanity itself was the prize for which they strove. Yet God's kingdom would certainly come. If for the present Satan seemed supreme, his triumph was but temporary. Righteousness, not sin, was the eternal element in the universe.

The passage from the religio-political messianism of the earlier Asmonean days to that of the passive resistance of the first Christian century was due to the increasing influence of this magnificent moral optimism, and is easily to be traced in the literature of pharisaism. In its early writings patriotism is still of this world. Only gradually did the images of the apocalypse cease to be political symbols and become literal figures. None the less, from the first the certainty of the triumph of God's kingdom and the establishment of the long-expected worldjudgment forbade appeal to arms. Even before the fully developed apocalyptic of the Enoch literature, Elijah was to come as the forerunner ${ }^{10}$ of the glorious, though still hardly individualized, Son of David ${ }^{1 x}$ and the eternal kingdom of Israel, ${ }^{12}$ and immortality is predicated of those alone who were to share in this messianic kingdom. ${ }^{\mathrm{x}}$ The Sibylline Oracles, it is true, show even in their most elevated passages that political hopes had not been entirely abandoned by those who most readily adopted the apocalypse as a literary form. The misery suffered under the Seleucidæ was quite too recent to be forgotten even by one who may have been a Jew of the dispersion. The judgment day was still political rather than individual, and the messianic age the day of a Jewish empire. ${ }^{14}$ The earthly representatives of Satan's kingdom, the enemies of Israel, were to

${ }^{20}$ Mal. 3:23, 24; Ecclus. $48: 10$.

II Ecclus. $47:$ I I ; I Macc. 2:57. ${ }^{12}$ Ecclus. $37: 25$; $44: 13$; 2 Macc. $14: 15$.

$\mathbf{x}_{3} 2$ Macc. $6: 26 ; 7: 9,11,14,20,23,29,33,36 ; 12: 42-45$. As to the fate of the wicked, see especially $7: 14$. There is, of course, a fair critical question as to whether these passages belong to the early Asmonean time. See Niese, Die Kritik der beiden Makkabäerbücher.

${ }^{14}$ Sib. Or., iii, 652-97, and especially 7 10-42, 755-60, 766-72. 
perish, the righteous Jews were to be eternally blessed. But national as this may be, it is just as distinctly non-revolutionary and eschatological.

It was, therefore, an easy step from the Sibylline Oracles to the original sections of Enoch (chaps. 72-105; I-36), for it was one of form rather than of content. The apocalypse was still symbolical, and in the unfaithful shepherds, the wild animals, the suffering and then militant sheep, it is not difficult to see the priests, the Syrians, and the Pious. ${ }^{15}$ Yet judgment is to fall upon the shepherds and the blind sheep, and the new Jerusalem is the new Israelitish state ${ }^{16}$ in which the Pious were to reign as the representatives of God. But in this new apocalyptic, as in the old, there is no call to revolution. Even the figure of the Messiah, ${ }^{17}$ though more distinct than in any previous literature, is far from central. No work is ascribed to him, and the author of the vision is content to say that when he takes up his kingdom all his subjects are to be like him, but rather as a gift of God than as the result of their own or his struggles. ${ }^{18}$

In the little "Weeks" apocalypse (9I: I 2-I7; 93), however, one discovers the transition to a more transcendental hope. A period of peace and joy follows the overthrow of the enemies of Israel, the angels alone are judged, all men repent, and a new heaven appears in which goodriess and happiness are eternal. There is no mention of a Messiah, and this fact, and the general character of its portrayal of the future, lead one to refer this section to another source than its context. This, however, in the light of Enoch, chaps. I-36, does not necessitate any radical change in date, but rather argues that even in its early years pharisaism was combining its hopes for the appearance of the eschatological kingdom with its political forecasts.

Transcendentalism becomes supreme in Enoch, chaps. I-36. In them the thought of an Israel triumphing without cataclysms or miracles is overshadowed by the picturing of the great judgment day. God appears, surrounded by myriads of angels,

${ }^{15}$ Enoch, 90:16-27. $\quad{ }^{16}$ Enoch, $90: 28-33 . \quad{ }^{17}$ Pictured as a white bull.

${ }^{18}$ Enoch, 90:37, 38. The sheep and other animals typifying the true Jews become white. 
mountains and hills meeting before him. The righteous dead, who have been living in paradise, are given still greater joys, while the wicked are sent to eternal suffering. ${ }^{19}$

From such a picture as this the transition was easy to the next group of Enoch visions (chaps. 37-7I), in which the literalizing of the apocalypse is all but complete. The Messiah is now distinctly individualized with a variety of names - Son of man, ${ }^{20}$ the Elect, the Anointed, the Righteous One. He is pre-existent ${ }^{2 x}$ and a judge ${ }^{22}$ conjointly with God himself. In this judgment all, both good and evil, even though dead, ${ }^{23}$ share. Kings and nobles suffer punishment ${ }^{24}$ with the evil angels. ${ }^{25}$ No sin goes unpunished, though, except in the case of the kings, ${ }^{26}$ repentance seems always possible through the mercy of God.27 The Jews of the dispersion return to Palestine,$^{28}$ and the Messiah reigns ${ }^{29}$ over a righteous nation happy in the enjoyment of peace and equality. ${ }^{30}$ Heaven joins the earth, and immortal men dwell together with angels in a world forever free from $\sin .^{3 x}$

In these visions it is difficult to see anything but the dreams of a glowing faith. Barring the vague hope for equality and the subjugation of oppressing kings, they contain nothing political or social. Symbolism itself has ceased to be symbolic and has become literal. Political rulers and parties are not to be seen in the chief actors of the new apocalypse, and the reader is

Enoch, $1: 4-9 ; 5: 4-9 ; 22: 5-13$.

${ }^{20}$ Unless the sections in which this term is used be held to be post-Christian (see a good summary of arguments for this position in STALKER, Christology of Jesus, App.), a view with which it is difficult to agree. According to some texts, in 62:5 and $69: 29$ the title "that Son of the woman" appears; this reading is rejected, however, by Charles, Book of Enoch, p. I64.

${ }^{2 x} 46: 1,2 ; 48: 3,6 ; 62: 7$.

$2245: 3 ; 47: 3 ; 50: 4 ; 62: 2$. Cf. Charles, Enoch, in loco.

${ }^{23} 5 \mathrm{I}: \mathrm{I}$. $\quad{ }^{25} 54: 5,6$; chap. 64 .

${ }^{24}$ Chaps. 62 and $63 . \quad{ }^{26} 63: 6$.

${ }^{27}$ The position given men in the heavenly kingdom is apparently determined by the time of their repentance. $C f$. chap. 50.

${ }^{28}$ Chap. 57. $\quad{ }^{29} 45: 3,4 . \quad{ }^{30} 53: 6,7$.

${ }^{31} 39: 5-12 ; 58: 3 ; 71: 16$. 
introduced into a germinant eschatology in which pharisaic dualism reaches a transcendental solution. ${ }^{32}$

The uncertainty as to the precise date when these visions of Enoch were composed makes it the easier to appreciate the influence of the new transcendentalism in the partial renascence during the last half-century before Christ of the older and more concrete messianic hope in the Psalms of Solomon. That these songs are of pharisaic origin can hardly be questioned. According to the belief of their author, misfortune never came to a nation except as a punishment for sin. That Judea was suffering, therefore, argued long-continued secret wrong-doing on the part of its rulers. The Romans, though their leader had experienced God's wrath,33 were but God's agents of punishment; ${ }^{34}$ the real offenders were the degenerate Asmonean high-priests. The precise faults of this house seem to have been $(a)$ their change of the kingless theocracy to a monarchy; $(b)$ in case a monarchy was inevitable, their presumption in usurping the throne of the divinely appointed Davidic family; (c) their misuse of their priestly office ; $(d)$ their surrender to Rome.

It should be remembered that the Pharisees had (in their Chasidim days) cheerfully submitted to the highpriesthood of the Asmonean house. It was not the displacement of the house of Zadok which displeased them, for the Asmoneans were priests, and any technical difficulties the Pharisees, with the people, were content to waive until some prophet should appear to solve them finally. It was the monarchy as such that the Pharisees opposed. The ideal Judea, composed of those who were righteous, was impossible as long as "sinners" controlled the state. ${ }^{35}$ A righteous king was therefore the first condition of that righteous and glorious state for which all Jews longed. ${ }^{36}$

From this point of view the messianic portrait of Pss. I7 and 18 is quite intelligible. In them the apocalyptic element is reduced to a minimum. The pious are indeed to rise from

3* It may be objected that $56: 5^{-8}$ presents political affairs. Undoubtedly this is true, but probably only as picturing the circumstances that called for apocalyptic comfort given in the visions as a whole. The section is in too distinctly a historical spirit to belong to visions themselves.

${ }^{33}$ Ps. Sol., $2: 30,31 . \quad{ }^{34} C f .2: 7,8,17 . \quad{ }^{35}$ Cf. $6: 2 . \quad{ }^{36} 7: 9 ; 9: 19$. 
the dead, ${ }^{37}$ but there is no clear correlation of this eschatology with the messianic hope. Indeed, the thought of a kingdom is in marked subordination to that of the Messiah. No picture could be more clearly drawn than his. Neither a sufferer nor a teacher, pre-existent nor miraculously born, a priest like the Asmoneans nor an eschatological wonder like the Son of man of Enoch, he is the mighty king, the vice-gerent of God. In character he is to be sinless,,$^{38}$ obtaining wisdom from God, ${ }^{39}$ and strong through the Holy Spirit.4 His capital is to be Jerusalem, which is first to be purged of all heathen, ${ }^{4^{I}}$ and his kingdom is to be composed of sanctified Jews, ${ }^{42}$ sons of God, among whom there will never be pride or oppression or unrighteousness of any sort. He is to conquer the entire heathen world, and even the sinners - by whom the Asmonean house may be meantwill be "convicted in the thoughts of their hearts" (vs. 27). The entire earth shall serve him, and he will have mercy only upon those who fear him.

Yet, strangely enough, this mighty king is not to be a man of war. $\mathrm{He}$ is to put no trust in horses or cavalry or bows or armies. His conquests are to be wrought "with the word of his mouth." 43 The expression is a true echo of pharisaism. The king is certainly not to be a teacher or a preacher or a philosopher, but the author of the psalm does not wish to be understood as counseling war, and therefore falls back on miracle. The Christ is to be so mighty that he does not need to fight.

The laissez-faire spirit of pharisaism as regards political evils could hardly be better joined with limitless hope. The world

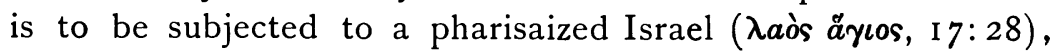
over whom a great king is to reign as the representative of God; but the messianic ideal of these psalms is farther from that of the Zealots than from that of the apocalypses. One sees in it an attempt to re-express the spirit of apocalyptic without the assistance of visions. As the nearest approach

${ }^{37} 3: 16 ; 14: 1-3,7$. For the wicked there is no such hope $\left(3: 13^{-15} ; 13: 10\right.$; I $4: 6 ;$ I $5:$ II).

\footnotetext{
${ }^{38}$ Ps. Sol., $17: 35,36$.

$4017: 37,42$.

42 Vss. 26, 32, 33, 36 .

39 I $7: 3$ I.

${ }^{41} 17: 25,30,31$.

43 I $7: 36-39$.
} 
made by pharisaism to picturing a literal Jewish state, it demonstrates how utterly unworldly even its non-apocalyptic messianism had grown. God's Messiah must come and miraculously establish the new and untranscendental kingdom. In the meantime pious Jews must wait in patience.

With the final establishment of the Roman suzerainty, the hope of pharisaism lost even the shadowy concreteness of these psalms, and turned unreservedly to apocalypses in which the judgment is, as might be expected, all-important. In the Assumption of Moses suffering is made the incentive, not only to religious faith, but also to confidence in the ultimate establishment of the kingdom of God, condemnation of all heathen, ${ }^{44}$ and the end of Satan. The kingdom and not the Messiah is central, and God is a great judge, granting salvation only to the kingdom's members. Even more central is the final judgment of both angels and men in the Secrets of Enoch.45 After it, there begins for the righteous who have entered the kingdom a new age, endless and blessed, without illness or sorrow of any sort. ${ }^{4}$ Of the Messiah or resurrection there is no mention. So, too, in the Book of Jubilees the judgment is the dominating element in the future, ${ }^{47}$ though, as always, the Jews are to be the gainers and the final world-rulers in an age of indescribable happiness. Again, neither resurrection nor Messiah is mentioned, but it is not difficult to correlate them with the predicted triumph of the kingdom of God over that of Satan.

The completion of this transcendentalism is to be seen in literature like the Apocalypse of Baruch and 4 Esdras occasioned by the destruction of Jerusalem. Like the authors of the earlier apocalypses, the new seers looked to a messianic kingdom upon earth whose capital should be a new Jerusalem which had come down from heaven. $4^{8}$ Over this kingdom the Messiah should reign until the earth itself should pass away ${ }^{49}$ and all enemies of Israel should have been punished. During these days the right-

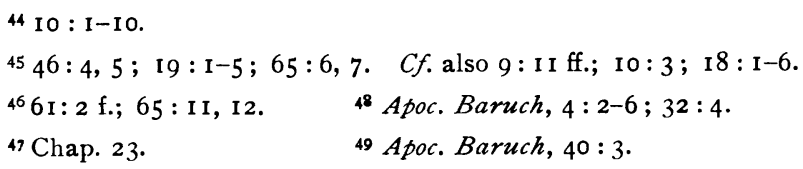


eous would live in the utmost happiness, the earth yielding prodigious harvests ${ }^{50}$ and wild. beasts losing all their ferocity. ${ }^{5 x}$ Unlike the earlier writers (unless we except Sibylline Oracles, iii, 97-807), the Apocalypse of Baruch regards the messianic kingdom as but temporary. It is followed by a general resurrection, after which comes the final judgment. ${ }^{22}$ When each man has been given his deserts, then begins the everlasting age in which time ceases, the righteous like angels dwell in heaven and not on the earth, and the wicked agonize in fire. ${ }^{53}$ In 4 Esdras the picture is more elaborated, but, with one exception, hardly different in essentials. The pre-existent Christ ${ }^{54}$ rises from the sea in company with Enoch, Moses, and Elijah. ${ }^{55}$ He destroys the united enemies of Israel ${ }^{56}$ without war, but with fire that proceeds from his mouth. ${ }^{57}$ The ten tribes of Israel return to dwell with their brethren in a new Jerusalem not made with hands, but which had come down from heaven..$^{8}$ At this point, however, appears a new element which one cannot help believing is in some measure due to Christian influences. The Messiah and all mankind die, the world being for an entire week locked in death. ${ }^{59}$ Then comes the general resurrection, and God establishes the judgment $^{60}$ in which the endless destiny of every man is fixed. The rewards and punishments of life have already been experienced in some degree, ${ }^{6 \mathrm{x}}$ but now the righteous go to an eternal paradise and the wicked to eternal hunger and pain. ${ }^{62}$ Thereafter God is supreme.

It is not necessary to trace the development farther into

50 Apoc. Baruch, 29:5. The same prophecy is said by Papias, on the authority of the elders who had heard John (IREn «US, Ag. Heresies, v, $33: 3,4$ ), to have been made by Jesus himself - a highly improbable statement.

${ }^{5}$ Chap. 73.

53 Apoc. Baruch, 51 : I-1 2.

52 Apoc. Baruch, chap. 30.

$5412: 32 ; 13: 26,52 ; 14: 9$.

554 Esdras, $6: 26$ ("they shall see the men who have been taken up, who have not tasted death from their birth," i. e., Enoch, Moses, Elijah); 1 3: 2, 3, 5, 25, 52.

${ }^{56} 12: 31-34$.

57 1 $3: 37,38$, an echo of Ps. Sol., $17: 39$, perhaps in its turn derived from Isa. $11: 4$.

$5^{8} 13: 39-47 ; 7: 26 ; 10: 55 ; 13: 36$. $597: 29,30 . \quad 607: 31-35$.

$6 \times 6: 5-74$, though these verses are not beyond question.

$628: 52-59$. 
the rabbinical literature. ${ }^{63}$ Enough has been said to show how utterly lacking in all social content was pharisaic messianism in the time of Jesus and the early church. Later, it is true, the rabbis were for a few years swept away from this non-revolutionary attitude and under Akiba and Bar Cochba attempted to establish a new Jewish state; but in the days of Paul such a program was clearly foreign to the program of the entire pharisaic group. ${ }^{64}$ For if we review the development seen in literary remains, the following elements of the messianism of pharisaism will appear essential :

I. The increasing emphasis upon the transcendental kingdom and the utter absence of any call to prepare for its coming, except as such a call may be involved in the general insistence upon righteousness.

2. The coming of the messianic period as determined wholly by God, and as not made dependent upon any human effort, whether it be repentance or revolution or social reform. With practical unanimity the Pharisees held that the new Jerusalem, the type of the kingdom, was already prepared in heaven, from which it was to descend to the earth. Its coming, therefore, was not the product of a social evolution, but cataclysmic, miraculous. Men must await its coming in patience.

3. The increasing prominence and individualizing of the Messiah, as the one who brings in the kingdom. His appearance is the chronological precursor of its coming.

4. The central position of the judgment as that by which the futures of all men are determined. No messianic hope omits it ; all messianism revolves about it. To be acquitted is to be admitted to paradise; to be condemned is to be sent to eternal suffering. It is the introduction to the eschatological element in pharisaic messianism. The righteous will be acquitted by God in this judgment, will pass through a resurrection, will be permitted to share in the endless bliss of the kingdom of heaven;

${ }^{6}{ }_{3}$ For instance, in Shemoneh Esreh, I0, II, 14, 15, 17.

${ }^{64}$ Josephus, though flattering the Flavian family (War, vi, $5: 4$ ), evidently believed that the Jewish race would yet beat down all peoples, for he refused to give the one interpretation to Dan., chaps. II and I2, which his context makes plain. Cf. Ant., $\mathbf{x}, \mathbf{I}: 7 ;$ War, iv, $6: 3$. 
the wicked will be condemned by God in the same judgment to everlasting misery, and-though pharisaism at this point wavered - will not share in the resurrection of the body.

It follows from these facts that righteousness is the one prerequisite to justification, and the consequent participation in the messianic reign and eternal bliss.

5. The messianic reign established on earth, but - though this is not universal-succeeded by a new age in which the Messiah is of no importance and God is supreme. In this new age the redeemed are to live in heaven.

In other words, pharisaic messianism may be summed up as : a hope for membership in an already existent heavenly kingdom to be brought from heaven by a suddenly appearing Messiah; for general judgment in which the righteous should be acquitted and the wicked condemned; for resurrection of the body and a life everlasting for the righteous; for an endless age in which God and happiness should be supreme and enjoyed forever by those whom he had justified.

In such a hope there is a call to individual righteousness during one's earthly life, but no call to social reform. The virtues to be cultivated are quiet submission to misfortune, patience, faith, hope, an observance of all of God's requirements, among which is love. Pride, the oppression of the righteous, and the disregard of the law of God will be the chief sins to be condemned.

Christianity took its rise in the period when these two forms of messianism, the revolutionary and the apocalyptic, were reaching their completion. We have now to see in what respects it was conditioned by each, and how much of each it may have perpetuated. 